\title{
An educational intervention to study the awareness of solar disinfection of drinking water among residents of an urban slum of a city in Central India
}

\section{Satish Saroshe, \\ A. K. Puranik', Sanjay Dixit, Suraj Sirohi, Bhagwan Waskel, Harish Shukla}

Department of Community Medicine, Mahatma Gandhi

Memorial Medical College, Indore, ${ }^{1}$ Community Medicine, Sri Aurobindo Institute of Medical Sciences Medical College, Indore,

Madhya Pradesh, India

Address for the Correspondence:

Dr. Satish Saroshe, Department of Community Medicine, Mahatma Gandhi Memorial Medical College, Indore - 452 001,

Madhya Pradesh, India.

E-mail: drsatishsaroshe@ gmail.com

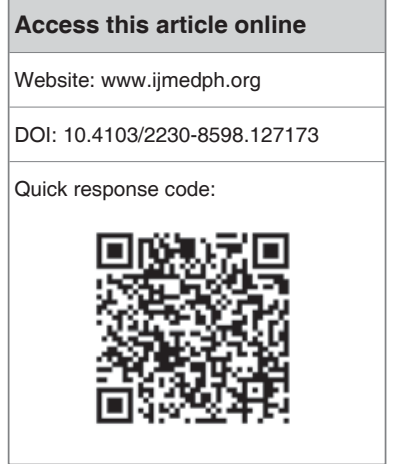

Solar disinfection (SODIS) is a simple, environmentally sustainable, low-cost solution for drinking water treatment at household level. It uses solar energy to destroy pathogenic microorganisms causing water borne diseases. Contaminated water is filled into transparent plastic bottles and exposed to full sunlight for $6 \mathrm{~h}$. During the exposure to the sun, the pathogens are destroyed. Objective: To study the awareness of SODIS of drinking water among residents of an urban slum. Materials and Methods: A crosssectional study imparting educational intervention to spread the awareness of SODIS of drinking water among residents of an urban slum. Result: A total of $50 \%$ increase in awareness regarding concept of SODIS; $66 \%$ increase in awareness regarding method of SODIS. The study was carried out with sample size of 100 which was not sufficient to corroborate the findings on a larger picture, needs more sample size to be incorporated which unfortunately was not contemplated owing to time constraint. Conclusion: It is recommended to find the utility of SODIS on a scientific basis and in Indian context, so that this cost-effective method can be utilized on a larger scale.

Key words: Household water treatment and safe storage, pathogenic microorganisms, plastic bottles, SODIS, solar disinfection, water borne diseases

\section{INTRODUCTION}

A total of 884 million people- $25 \%$ of whom live in sub-Saharan Africa-still use unimproved sources for drinking water. ${ }^{[1]}$ At the current rate of progress, the world is expected to exceed the Millennium Development Goal (MDG) target of halving the proportion of the population without sustainable access to safe drinking water. Even so, 672 million people will still lack access to improved drinking water sources in 2015. ${ }^{[2]}$

Household water treatment and safe storage (HWTS) interventions are proven to improve water quality and reduce diarrheal disease incidence in developing countries. Four of these proven HWTS options-chlorination, solar disinfection (SODIS), ceramic filtration, and flocculation/disinfection-are widely implemented in developing countries. Organizations wanting to develop HWTS programs are often faced with the difficult decision of selecting which option or options are appropriate for their particular circumstances. The most appropriate HWTS option for a location depends on existing water and sanitation conditions, water quality, cultural acceptability, implementation feasibility, availability of HWTS technologies, and other local conditions. ${ }^{[3]}$

SODIS is a simple, environmentally sustainable, low-cost solution for drinking water treatment at household level for people consuming microbiologically contaminated raw water. SODIS uses solar energy to destroy pathogenic microorganisms causing water borne diseases and therewith it improves the quality of drinking water. Pathogenic microorganisms are vulnerable to two effects of the sunlight: radiation in the spectrum of ultraviolet (UV)-A light (wavelength $320-400 \mathrm{~nm}$ ) and heat (increased water temperature). A synergy of these two effects occurs, as their combined effect is much greater than the sum of the single effects. This means that the mortality of the microorganisms increases when they are exposed to both temperature and UV-A light at the same time. SODIS is ideal to disinfect small 
quantities of water of low turbidity. Contaminated water is filled into transparent plastic bottles and exposed to full sunlight for $6 \mathrm{~h}$. During the exposure to the sun, the pathogens are destroyed. If cloudiness is greater than $50 \%$, the plastic bottles need to be exposed for 2 consecutive days in order to produce water safe for consumption. However, if water temperatures exceed $50^{\circ} \mathrm{C}, 1 \mathrm{~h}$ of exposure is sufficient to obtain safe drinking water. The treatment efficiency can be improved if the plastic bottles are exposed on sunlight reflecting surfaces such as aluminium- or corrugated iron sheets. ${ }^{[4]}$

SODIS was developed in the 1980s to inexpensively disinfect water used for oral rehydration solutions used to treat diarrhea. In 1991, the Swiss Federal Institute for Environmental Science and Technology (SANDEC, EAWAG) began to investigate and implement SODIS as a HWTS option, to prevent diarrhea in developing countries. Users of SODIS fill 0.3-2.0 liter plastic soda bottles with low-turbidity water, shake them to oxygenate, and place the bottles over the roof or rack for $6 \mathrm{~h}$ (if sunny) or 2 days (if cloudy). The combined effects of UV-induced deoxyribonucleic acid alteration, thermal inactivation, and photooxidative destruction inactivate disease-causing organisms. In the laboratory, SODIS has been proved to inactivate the viruses, bacteria, and protozoa that cause diarrheal diseases. Field data have also shown reductions of bacteria in developing country waters treated with SODIS. In four randomized, controlled trials, SODIS has resulted in reductions in diarrheal disease incidence ranging from $9 \%$ to $86 \%{ }^{[5]}$ The present study was undertaken with aim to study the awareness of SODIS of drinking water among residents of an urban slum of a city in central India and to improve their knowledge with the help of an educational intervention, also to cite recommendations based in the present study.

\section{MATERIALS AND METHODS}

\section{Study design}

Cross-sectional study

\section{Study area}

Urban slum of Indore district

\section{Study subjects}

100 inhabitants each of 100 selected households in this urban slum (household-A group of persons who normally live together and took food from a common kitchen-National Sample Survey Office (NSSO) 1999).

\section{Sampling technique}

Simple random sampling using lottery method

\section{Ethical clearance}

Written informed consent was obtained from each study subject

\section{Study duration}

3 months duration (Oct. 2012-Dec 2012)

\section{Study Tool}

i. A predesigned pretested semistructured questionnaire

ii. Pamphlets, posters, and AV aids along with lecture method for educational intervention

\section{Inclusion criteria}

Inhabitants of selected households of identified urban slum who gave consent.

\section{Exclusion criteria}

Inhabitants of selected households of identified urban slum who did not give consent.

\section{Study process}

The study was conducted in 100 inhabitants each of 100 selected households in this urban slum of Indore district of Madhya Pradesh. The semistructured questionnaire, included the biographical data of the inhabitants that is age, address, education, occupation, and type of family was used for demographical data collection.

\section{Analysis}

The data were analyzed using appropriate statistical software (SPSS). McNemar's test and Pearson's chi-square test were used wherever required.

\section{RESULT}

Present study was carried out in 100 household of urban slum of Indore, Among the participants most were of age group 35-45 years $(56 \%)$. A total of $58 \%$ participants were females and $42 \%$ were males. A total of $33 \%$ participants were graduates and $31 \%$ were higher secondary pass. And 20\% participants were illiterate. $55 \%$ respondents belong to joint family and $45 \%$ to nuclear family. 34\% were skilled workers, $22 \%$ unskilled workers, and $14 \%$ were shop owners/clerical (based on modified Kuppuswamy classification).

Table 1 suggests that 75\% households were using water from municipal tap. 15\% were using tube well/well and $10 \%$ were dependent on water tankers. $80 \%$ were of the opinion that they get sufficient drinking water from principal sources throughout year [Table 2].

As far as method used for filtration of drinking water was concerned [Table 3, Figure 1] 62\% filter drinking water with cloth, $9 \%$ use chemicals (alum, chlorine, $\mathrm{KMnO}_{2}$ ) and $8 \%$ use boiling. All those who use boiling, use liquid petroleum gas (LPG) cylinder for this purpose [Table 3a]. 21\% do not use any filtration method most

\section{Table 1: Source of the drinking water}

\begin{tabular}{lcc}
\hline Source & No. & Percentage (\%) \\
\hline Municipal tap & 75 & 75 \\
Tube well/well & 15 & 15 \\
Others* & 10 & 10 \\
\hline
\end{tabular}

*Water tankers both private and municipal corporation 
commonly due to lack of awareness. $96 \%$ respondents store water in home utensils [Table 4]. These storage utensils are washed daily in $73 \%$ cases, alternate days in $20 \%$ cases, alternate days in $20 \%$ cases, and weekly in 7\% cases [Table 5].

66\% respondents did not know about HWTS option [Table 6]. After education intervention, there was 53\% increase in awareness regarding the same $\left(\chi^{2}=15.625 ; P=0.000\right.$, statistical significant), $90 \%$ respondents were unaware of SODIS full name (SODIS). The educational intervention resulted in $43 \%$ increase in awareness of SODIS full name (Solar Disinfection) $\left(\chi^{2}=11.091 ; P=0.001\right.$, statistically significant) [Table 7].

A total of $60 \%$ respondents were unaware of the concept of SODIS. After educational session, $90 \%$ were aware $50 \%$ increase in awareness, $\chi^{2}=14.359, P=0.000$, statistically significant) [Table 8].

A total of $90 \%$ study subjects did not know about method of SODIS. Educational intervention increase the awareness by $66 \%$ $\left(\chi^{2}=24.502 ; P=0.000\right.$, statistically significant) [Table 9].

Both pre- and postintervention, respondents were well aware regarding the spread of water borne disease due to contaminated water (nonpurification of water) [Table 10].

\section{DISCUSSION}

As per the knowledge of authors, there is no study so far in India of this type to assess the awareness of SODIS and to incorporate knowledge among respondents of techniques and feasibility of SODIS. Since both World Health Organization and Centre of Disease Control Atlanta (CDC) have reckoned SODIS as technically simplest and most practical and economical solar treatment system of water. As per CDC Atlanta document, in Assam University provided technical and training support for a SODIS promotion project with a local nongovernmental organization. ${ }^{[5]}$

As per NSSO report $70 \%$ of urban households use tap in our study, $75 \%$ households were using municipal tap. The NSSO report on drinking water sanitation and hygiene in India claims that 85\% urban households get sufficient drinking water from their principal source. In our study, $80 \%$ had the same response. The NSSO report claims that $35 \%$ urban households filter the drinking water and $11 \%$ boil it, whereas in the present study $62 \%$ urban households filter the

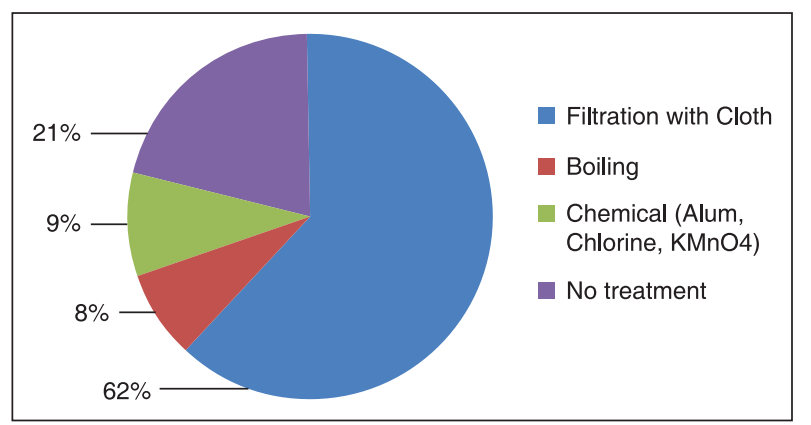

Figure 1: Methods used for filtration of drinking water drinking water with cloth, $8 \%$ boil it, and $9 \%$ use chemicals (alum, chlorine, and $\mathrm{KMnO}_{4}$ ). In the present study, all the respondents who boil the water use LPG cylinder hike of LPG cylinder prices \& the

\begin{tabular}{lcc} 
Table 2: Do you get sufficient drinking water from \\
principal sources throughout the year? \\
\cline { 2 - 3 } Response & \multicolumn{2}{c}{ Total $[\mathbf{N = 1 0 0}$ (100\%)] } \\
\cline { 2 - 3 } & No. & Percentage (\%) \\
\hline Yes & 80 & 80 \\
No & 20 & 20 \\
\hline
\end{tabular}

$80 \%$ respondents opined sufficient drinking water from principal sources throughout year

\begin{tabular}{lcc} 
Table 3: Methods used for filtration of drinking \\
water & \multicolumn{2}{c}{ Total households } \\
\cline { 2 - 3 } Method employed & No. & Percentage (\%) \\
\hline Filtration with cloth & 62 & 62 \\
Boiling & 8 & 8 \\
Chemical (alum, chlorine, $\mathrm{KMnO}_{4}$ ) & 9 & 9 \\
No treatment & 21 & 21 \\
Total & 100 & 100 \\
\hline
\end{tabular}

\begin{tabular}{lcc} 
Table 3: (a) If boiling is used as method then \\
method employed for boiling \\
\hline Method employed & \multicolumn{3}{c}{ Total households } \\
\cline { 2 - 3 } & No. & Percentage (\%) \\
\hline LPG cylinder & 8 & 100 \\
others & 0 & 0 \\
Total & 8 & 100 \\
\hline
\end{tabular}

LPG = liquid petroleum gas

$\begin{aligned} & \text { Table 4: Storage of drinking water in home } \\
& \text { utensils }\end{aligned}$
\begin{tabular}{lcc} 
Response & \multicolumn{2}{c}{ Total $[N=100(\mathbf{1 0 0 \% )}]$} \\
\cline { 2 - 3 } & No. & Percentage (\%) \\
\hline Yes & 96 & $96^{*}$ \\
No & 4 & 4 \\
\hline
\end{tabular}

${ }^{*} 96 \%$ respondents store drinking water in home utensils

\begin{tabular}{lcc} 
Table 5: Frequency of washing utensils of water \\
\hline Method employed & \multicolumn{2}{c}{ Total households } \\
\cline { 2 - 3 } & No. & Percentage (\%) \\
\hline Daily & 73 & $73^{*}$ \\
Alternate days & 20 & 20 \\
Weekly & 7 & 7 \\
Total & 100 & 100 \\
\hline
\end{tabular}

${ }^{*} 73 \%$ respondents wash the utensils daily

Table 6: Awareness of household water treatment
and safe storage
\begin{tabular}{lcccccc}
\hline \multirow{2}{*}{ Response } & \multicolumn{2}{c}{ Preintervention } & & \multicolumn{2}{c}{ Postintervention } \\
\cline { 2 - 3 } \cline { 5 - 6 } & No. & Percentage (\%) & & No. & Percentage (\%) \\
\hline Yes & 34 & 34 & & 87 & 87 \\
No & 66 & 66 & & 13 & 13 \\
\hline
\end{tabular}

$53 \%$ increase in awareness of household water treatment and safe storage $\left(\chi^{2}=15.625\right) P=0.000$ (statistically significant) 


\begin{tabular}{lcccccc}
\multicolumn{2}{l}{ Table 7: } & \multicolumn{2}{c}{ Awareness of SODIS } & & \multicolumn{2}{c}{ solar disinfection } \\
\cline { 2 - 3 } Response & \multicolumn{2}{c}{ Preintervention } & & \multicolumn{2}{c}{ Postintervention } \\
\cline { 2 - 3 } \cline { 5 - 6 } & No. & Percentage (\%) & & No. & Percentage (\%) \\
\hline Yes & 10 & 10 & & 53 & 53 \\
No & 90 & 90 & & 47 & 47 \\
\hline
\end{tabular}

$43 \%$ increase in awareness of solar disinfection $\left(\chi^{2}=11.091\right) P=0.001$ (statistically significant)

\begin{tabular}{|c|c|c|c|c|}
\hline \multirow[t]{2}{*}{ Response } & \multicolumn{2}{|c|}{ Preintervention } & \multicolumn{2}{|c|}{ Postintervention } \\
\hline & No. & Percentage (\%) & No. & Percentage (\%) \\
\hline Yes & 40 & 40 & 90 & 90 \\
\hline No & 60 & 60 & 10 & 10 \\
\hline
\end{tabular}

$50 \%$ increase in awareness regarding concept of solar disinfection $\left(\chi^{2}=14.359\right)$ $P=0.000$ (statistically significant)

\begin{tabular}{|c|c|c|c|c|}
\hline \multirow[t]{2}{*}{ Response } & \multicolumn{2}{|c|}{ Preintervention } & \multicolumn{2}{|c|}{ Postintervention } \\
\hline & No. & Percentage (\%) & No. & Percentage (\%) \\
\hline Yes & 10 & 10 & 76 & 76 \\
\hline No & 90 & 90 & 24 & 24 \\
\hline
\end{tabular}

$66 \%$ increase in awareness regarding method of solar disinfection $\left(\chi^{2}=24.502\right)$ $P=0.000$ (statistically significant)

\begin{tabular}{|c|c|c|c|c|}
\hline \multirow[t]{2}{*}{ Response } & \multicolumn{2}{|c|}{ Preintervention } & \multicolumn{2}{|c|}{ Postintervention } \\
\hline & No. & Percentage (\%) & No. & Percentage (\%) \\
\hline Yes & 80 & 80 & 90 & 90 \\
\hline No & 20 & 20 & 10 & 10 \\
\hline
\end{tabular}

cap on annual LPG cylinder quota makes boiling a very expensive option for boiling. On the contrary, SODIS is a cheap, cost-effective, and economical method. ${ }^{[6]}$

Field tests show that transparent positron emission tomography (PET) bottles of $2 \mathrm{~L}$ volume are very appropriate containers for SODIS. Coloured bottles do not transmit enough UV radiation; these bottles should not be used for SODIS. ${ }^{[4]}$ Authors also feel that this will lead to a proper and judicious usage of PET plastic bottles.

The EAWAG consortium has clearly mentioned that awareness alone is not enough. But there are definite advantages of SODIS. The benefits of SODIS are as follows:

Proven reduction of viruses, bacteria, and protozoa in water; Proven reduction of diarrheal disease incidence in users; Acceptability to users because of the simplicity of use; No cost to the user after obtaining the plastic bottles; Minimal change in taste of the water; and, Although SODIS does not have a chemical residual, recontamination is unlikely because water is served directly from the small, narrow-necked bottles with caps in which it is treated. ${ }^{[3]}$

At the same time, there are certain disadvantages of SODIS. The major drawbacks of SODIS are as follows:

The need for pretreatment (filtration or flocculation) of waters of higher turbidity; User acceptability concerns because of the limited volume of water that can be treated at once and the length of time required to treat water; and, The large supply of intact, clean, suitable plastic bottles required. ${ }^{[3]}$

SODIS is most appropriate in areas where there is availability of bottles and community motivation and training for users on how to correctly and consistently use SODIS for treating household drinking water. ${ }^{[3]}$

Over 2 million people in 28 developing countries use SODIS for daily drinking water treatment. Over 2 million people in 28 developing countries use SODIS for daily drinking water treatment. ${ }^{[3]}$

A controlled field trial has been successfully carried out regarding SODIS of drinking water and diarrhoea in Maasai children. ${ }^{[7]}$ Scientific evidence clearly opines that SODIS of water reduces diarrhoeal disease. ${ }^{[8-11]}$

Conroy et al., ${ }^{[12]}$ are of the opinion that SODIS of drinking water protects against cholera in children under 6 years of age.

The study was carried out with sample size of 100 which was not sufficient to corroborate the findings on a larger picture, needs more sample size to be incorporated which unfortunately was not contemplated owing to time constraint. Considering the potential of SODIS which the authors found they recommend to find the utility of SODIS on a scientific basis and in Indian context so that this cost-effective method can be utilized on a larger scale for the betterment of society.

\section{REFERENCES}

1. Available from: Website http: //www.unicef.org/eapro/JMP-2010Final.pdf [Last accessed on 2013 Mar 15].

2. Available from: Website whqlibdoc.who.int/publications/2010/ 9789241563956_eng_part2.pdf [Last accessed on 2013 Mar 15].

3. Available from: Website www.cdc.gov/safewater/publications_pages/ options-sodis.pdf [Last accessed on 2013 Mar 15]

4. Available from: Website www.sodis.ch/methode/anwendung/ ausbildungsmaterial/.../manual_e.pdf'[Last accessed by authors on 2013 Mar 15].

5. "Household Water Treatment Options in Developing Countries: Solar Disinfection (SODIS) CDC-January 2008" Available from: www.cdc.gov/ safewater/solardisinfection.html [Last accessed on 2013 Mar 15].

6. NSSO Drinking Water, sanitation and hygiene in India Available from: 164.100.34.62/index.php/catalog/93/download/1142 [Last accessed on 2013 Mar 15].

7. Conroy RM, Elmore-Meegan M, Joyce T, McGuigan KG, Barnes J. Solar disinfection of drinking water and diarrhoea in Maasai children: A controlled field trial. Lancet 1996;348:1695-7.

8. Conroy RM, Meegan ME, Joyce T, McGuigan KG, Barnes J. Solar disinfection of water reduces diarrhoeal disease: An update. Arch Dis Child 1999;81:337-8. 
9. Hobbins M, Mäusezahl D, Tanner M. Home-based drinking water purification: The SODIS Health Study, Bangladesh. Swiss Tropical Institute, Basel, Berkeley, Rajshahi; 2000.

10. Curtis V, Cairncross S, Yonli R. Domestic hygiene and diarrhoea pinpointing the problem. Trop Med Int Health 2000;5:22-32.

11. Ise $T$, Tanabe $Y$, Sakuma F, Jordan O, Serrate E, Pena H. Clinical evaluation and bacterial survey in infants and young children with diarrhoea in the Santa Cruz District, Bolivia. J Trop Pediatr 1994;40:369-74.

12. Conroy RM, Meegan ME, Joyce T, McGuigan KG, Barnes J. Solar disinfection of drinking water protects against cholera in children under 6 years of age. Arch Dis Child 2000;185:293-5.

How to cite this article: Saroshe S, Puranik AK, Dixit S, Sirohi $\mathrm{S}$, Waskel B, Shukla H. An educational intervention to study the awareness of solar disinfection of drinking water among residents of an urban slum of a city in Central India. Int J Med Public Health 2014;4:125-9.

Source of Support: Nil, Conflict of Interest: None declared. 